\title{
Beyond Gun Control: Implementing Mental Health Interventions for the School Shooting Crisis in California
}

\author{
Agnes M. Varghese ${ }^{1}$, Danielle E. Delany' ${ }^{1}$, Morgan L. Dundon ${ }^{2}$ \\ ${ }^{1}$ University of California, Riverside, Developmental Psychology Program, Riverside, CA \\ ${ }^{2}$ University of California, Riverside, Materials Science and Engineering Program, Riverside, CA \\ http://doi.org/10.38126/JSPG170212 \\ Corresponding author: agnes.varghese@email.ucr.edu \\ Keywords: school shootings; mental health interventions; social-emoțional learning; California
}

\begin{abstract}
Executive Summary: Over the last 10 years, the United States has witnessed a striking increase in school shootings (Riedman and O'Neil 2020). Most legislation addressing the issue has been focused on gun control with liberal states such as California passing stringent gun laws. However, it is important to acknowledge that the school shooting crisis is a multifaceted problem that will not be resolved by gun regulations alone. California should establish socialemotional learning programs in K-12 schools to help address the underlying issues that drive individuals to gun violence. These programs will provide students with the skills necessary to reduce aggressive behaviors as well as increase overall student well-being and academic achievement (Espelage et al. 2013). Along with gun control measures, California's policymakers should establish social-emotional learning programs in K-12 schools to reduce the number of school shooting incidents. Effective implementation of such programs could transform California from the state with the highest rate of school shootings in the country to an exemplary model for other states to follow in tackling the school shooting crisis.
\end{abstract}

\section{Statement of issue}

More school shootings occur in the United States than any other country-57 times more than other major industrialized nations combined (Grabow and Rose 2018). The tragedies at Columbine High School (1999), Sandy Hook Elementary School (2012), and Marjory Stoneman Douglas High School (2018), amongst many other K-12 institutions, strongly signify the need to take action to resolve this national emergency.

The Center for Homeland Defense and Security defines school shootings as situations where "a gun is brandished, is fired, or hits school property for any reason, regardless of the number of victims, time, day of the week, or reason (Riedman and O'Neill 2018)." Using this definition, in the 50 years between 1970 and 2019, 1,508 shooting incidents have occurred on $\mathrm{K}-12$ school grounds, with a substantial spike in the number of cases in the last few years. A record-high number of 116 shootings occurred in 2018, followed by a close second of 112 shootings in 2019 (Figure 1; Riedman and O'Neill 2020).

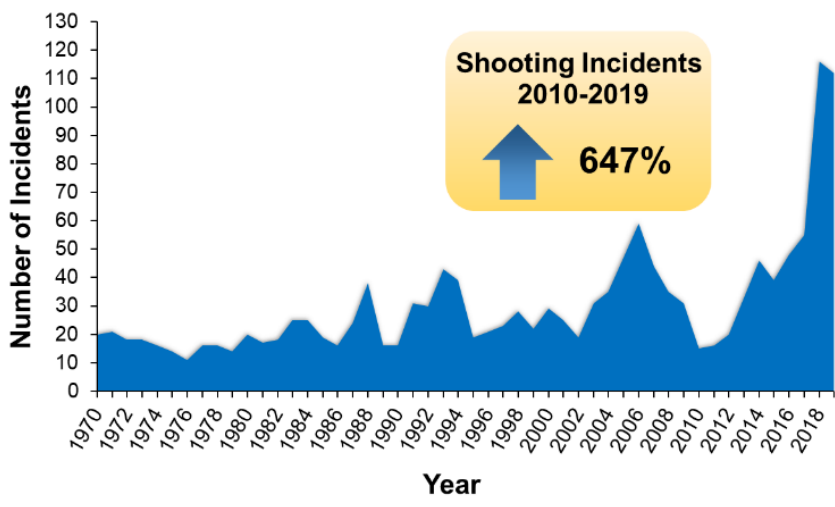

Figure 1: K-12 school shooting incidents in the U.S. by year; Figure adapted from Riedman and O'Neil 2020.

California leads the nation in the number of incidents at 170 school shootings during the last half century, 
with the next two highest states, Texas and Florida, at 138 and 94, respectively. California has had a 166\% rise in school shootings over the last ten years, with 8 occurring in 2019 alone (Riedman and O'Neill 2020). The Golden State must heed these numbers and lead the nation in developing effective methods to combat this crisis. If not, the United States will continue to witness the killing of innocent children along with the fear and grief instilled in those communities who have lost loved ones.

\section{Political status}

Guns are responsible for $15 \%$ of fatalities among children and adolescents, second only to motor vehicle crashes (Cunningham et al. 2018). In an attempt to reduce the number of lives taken from school shootings and other gun-related incidents, left-leaning policymakers have proposed several federal bills restricting the sale and circulation of guns. They argue that the number of casualties is devastatingly high because would-be perpetrators can easily access this weaponry which are highly effective killing tools. Right-leaning policymakers have fought against this interpretation, claiming that these restrictions threaten Americans' Second Amendment right to bear arms. This contention between parties has stunted stringent gun laws from passing at the federal level.

California has taken a different tactic. In the last year, state lawmakers have enacted a suite of gun control measures that:

- Prohibit individuals under 21 from buying semi-automatic center-fire rifles (SB 61).

- Give teachers the ability to seek gun violence restraining orders that would allow police to remove guns from individuals who are threatening to commit gun violence (AB 61).

- Enact charges/penalties for owners of unlocked guns that are taken out of the home by children (SB 172).

These new laws aim to decrease access to guns by youths and individuals threatening school communities. However, there is still widespread illegal access available. Furthermore, as some legislators have argued, these laws do not address the underlying reasons individuals choose to commit school shootings. To address both sides of this issue, other measures that tackle the root of violent behaviors need to be implemented in addition to gun control.

These types of mental health interventions within the education system can have a large impact in addressing the school shooting crisis. A majority of school shooters are current or former students of the school where they commit shootings (Riedman and 0 'Neill 2020). Many of these shooters (75\%) report depression, suicide ideation, and/or plans before the act (Vossekuil et al. 2002). In $87 \%$ of cases, they also describe low self-worth as a result of bullying victimization (Lee 2013; Vossekuil et al. 2002). However, these mental health-related issues are not exclusive to school shooters. 1 in 5 young people struggle with severe mental health problems, and many more have less severe mental health issues (Merikangas et al. 2010). Additionally, 24\% of teens report threatening or physically harming others as acceptable behavior when angered (Josephson Institute of Ethics 2012). Therefore, implementing effective mental health programs in schools will not only be a preventative measure against school shootings, but a productive step towards increasing the overall emotional stability and well-being of all students. To kickstart these programs, funding should come from The Mental Health Student Services Act of 2019 (SB 75), which funds prevention and early intervention programs for children and youth in California schools, as well as the hiring of additional mental health personnel.

\section{Policy options}

i. Option 1: Implementing a statewide social-emotional learning (SEL) program

Social-emotional skills allow individuals to understand and manage their own emotions, display empathy for others, and develop positive interpersonal relationships (Berman et al. 2018). Various school-based SEL programs incorporate these skills, including the Second Step Program (Frey et al. 2000; Wike and Fraser, 2009; Paolini 2015). This extensively researched, evidence-based curriculum has been successfully implemented in over 26,000 schools worldwide and is endorsed by the Department of Education (Second Step 2020). In this program, teachers are trained to implement developmentally-appropriate lessons on topics such as empathy, communication, emotion regulation, problem-solving, and bullying (Frey et al. 2000). This 
method of intervention proactively works to prevent school shootings by teaching children non-violent conflict resolution. Additionally, children who feel more connected to others have less desire to harm each other. The lessons in Second Step are ageadjusted (Wike and Fraser, 2009) and administered to students in 50-minute weekly sessions throughout the school year (Espelage et al. 2013). California should implement a mandatory SEL program following the model of Second Step in all K-12 schools throughout the state.

\section{Advantages}

This program would be inclusive to all $\mathrm{K}-12$ students in the California school system. Prior research has constructed a typical school shooter profile (e.g., white male, interested in violence, history of trauma; Langman 2009). However, predictive power is limited. The vast majority of individuals fitting the profile do not commit shootings, while some shootings are committed by individuals not fitting the profile (O'Toole 2009). Therefore, it is ideal to include all students as an extensive preventative measure. Also, through this curriculum students will gain skills in empathy, anger management, problem solving, and impulse control (Frey et al. 2000). While this program has not been directly studied in connection to school shootings, it is tied to reductions in aggressive and violent behaviors (e.g., 42\% decrease in physical aggression; Espelage et al. 2013), which are evident in school shooting perpetrators. It also shows a $20 \%$ reduction in bullying, which is a known risk factor for school shooters (Espelage et al. 2015). Additional positive outcomes include increased prosocial behaviors and academic achievement (Low et al. 2015; Wenz et al. 2018). Further, Columbia University conducted a benefit-cost analysis on SEL interventions and found that Second Step has an average return on investment of $\$ 11$ for every $\$ 1$ spent (Belfield et al. 2015). Reducing incidents of aggression helps decrease costs such as medical expenses. The value of this reduction surpasses the costs of SEL instruction (Belfield et al. 2015).

\section{Disadvantages}

This program would require a 4-hour training session (Belfield et al. 2015) and additional responsibilities on the part of the teaching staff. Given the plethora of duties that teachers already have, this may be difficult to include into their rotation. However, research shows that $82 \%$ of teachers are interested in obtaining training in SEL (Bridgeland et al. 2013). An additional disadvantage is that parents may be hesitant to have any of their children's school instruction time dedicated to the development of skills that might not seem as directly "academically" relevant. Yet, researchers have calculated that only $3 \%$ of instructional time will be dedicated to SEL (Belfield et al. 2015).

\section{ii. Option 2: Increasing counselor-to-student ratios}

The Pupil Health: Mental Health Professionals bill, introduced in 2019 (AB-8; currently awaiting hearing in the Senate), aims to have one counselor available for every 600 students during school hours. California currently averages one counselor per 682 students, whereas the national average is one counselor per 441 students (Mann et al., 2019). If this bill passes, the state would still be behind the rest of the nation in providing access to mental health professionals. Moreover, according to the American School Counselor Association (ASCA), there should be one counselor for every 250 students to ensure sufficient access to mental health resources (ASCA 2017). This bill should be amended to meet the standards of the ASCA's 1:250 counselor-to-student ratio. Additionally, the amendment should instruct counselors to assess and promote positive school climate, foster social, behavioral, emotional, and academic success for students, and be trained in interventions to resolve conflicts and assist troubled students (ASCA 2019).

\section{Advantages}

Increased counselor-to-student ratios provide students with better access to mental health professionals in the school atmosphere. This is linked to stronger relationships between counselors and students, and increased counselor effectiveness (Reback 2010; Boser, Poppen and Thompson, 1988). Counselors are often the first to be aware of students who are experiencing problems or are at risk for violence (Froeschle and Moyer, 2004; Mann et al., 2019). While there is not research exploring the effects of ratios on school shootings specifically, research shows that reduced counselor-to-student ratios are linked to decreased recurrences of student disciplinary problems, and increased graduation and school attendance rates (Carrell and Carrell, 2006; Lapan et al. 2012). 


\section{Disadvantages}

Hiring more counselors may not be effective on its own. Students who are experiencing mental health difficulties may not seek out this resource or may be deterred from doing so. In 2010, only $12.3 \%$ of youths sought mental health treatment in schools (SAMHSA et al. 2010), although the rate of mental illness is as high as 46\% (Merikangas et al. 2010). Additionally, parents' perceptions of mental health treatment and counseling can impact whether a child gets service at all or ends treatment prematurely. Moreover, these negative perceptions correlate with cancelling or missing sessions (Langer et al. 2015; Kern et al. 2017).

\section{iii. Option 3: Inaction}

Inaction would indicate a primary reliance on current state gun legislation in California. While gun laws may decrease legal access to guns and create legal consequences for adults who allow children to obtain guns, it is unclear if they will reduce school shooting rates.

\section{Advantages}

Inaction would place no additional responsibility on K-12 schools because they would not need to provide SEL training to teachers or hire additional counselors.

\section{Disadvantages}

If schools do not implement mental health interventions that address the psychological roots of violent behavior, it is likely that the increasing trend of school shooting incidents will continue to climb.

\section{Policy recommendation}

California legislators should pass effective means in addition to gun control to address the school shooting crisis. Gun regulation is only one facet of the issue. The SEL program described in Option 1 will be the most effective approach. It reaches every student and provides the skills to implement non-violent methods of conflict resolution. This is a program that directly works to increase the psychological well-being of all students, whether they are at risk of becoming a school shooter or not and has potential for bipartisan support.

However, the benefits of reducing the state's average counselor-to-student ratio must not be overlooked. This practice should be implemented given adequate resources. Measures in addition to mental health services and gun regulation include heightened school security and expanded scientific research on gun violence. Public health emergencies, such as school shootings, are multifaceted issues, requiring multifaceted approaches.

For the good of our state and our nation, the school shooting crisis must be examined from every angle. While children are the most vulnerable stakeholders, teachers, staff, parents, and the larger community are all impacted. Legislators in California should enact effective policies that the rest of the nation can model in the fight against school shootings. This should begin with SEL interventions that address the root causes of violent behavior. Given that instating this policy initiative takes time and resources, it is imperative to act now. Lives are at stake.

\section{References}

American School Counselor Association (ASCA). 2019. "The School Counselor and Prevention of SchoolRelated Gun Violence." https://www.schoolcounselor.org/asca/media/a sca/PositionStatements/PS GunViolence.pdf

American School Counselor Association (ASCA). 2017. "The School Counselor and School Counseling Programs."

https://www.schoolcounselor.org/asca/media/a sca/PositionStatements/PS ComprehensiveProgr ams.pdf

Belfield, Clive, A. Brooks Bowden, Alli Klapp, Henry Levin, Robert Shand, and Sabine Zander. 2015. "The Economic Value of Social and Emotional
Learning." Journal of Benefit-Cost Analysis 6 (3): 508-44. https://doi.org/10.1017/bca.2015.55

Berman, Sheldon, Sydney Chaffee, and Julia Sarmiento. 2018. "The Practice Base For How We Learn; Supporting Students' Social, Emotional, and Academic Development." National Commission on Social, Emotional, and Academic Development, The Aspen Institute. https://assets.aspeninstitute.org/content/upload s/2018/03/CDE-Practice-Base FINAL.pdf

Boser, Judith A., William A. Poppen, and Charles L. Thompson. 1988. "Elementary School Guidance Program Evaluation: A Reflection of StudentCounselor Ratio." The School Counselor 36 (2): 125-35. 
Bridgeland, John, Mary Bruce, and Arya Hariharan. 2013. "The Missing Piece: A National Teacher Survey on How Social and Emotional Learning Can Empower Children and Transform Schools. A Report for CASEL." Civic Enterprises.

Carrell, Scott E, and Susan A Carrell. 2006. "Do Lower Student to Counselor Ratios Reduce School Disciplinary Problems?" Contributions to Economic Analysis 5 (1): 26. https://doi.org/10.2202/1538-0645.1463

Cunningham, Rebecca M., Maureen A. Walton, and Patrick M. Carter. 2018. "The Major Causes of Death in Children and Adolescents in the United States." New England Journal of Medicine 379 (25): 246875. https://doi.org/10.1056/NEJMsr1804754

Espelage, Dorothy L., Chad A. Rose, and Joshua R. Polanin. 2015. "Social-Emotional Learning Program to Reduce Bullying, Fighting, and Victimization Among Middle School Students With Disabilities." Remedial and Special Education 36 (5): 299-311. https://doi.org/10.1177/0741932514564564

Espelage, Dorothy L., Sabina Low, Joshua R. Polanin, and Eric C. Brown. 2013. "The Impact of a Middle School Program to Reduce Aggression, Victimization, and Sexual Violence." Journal of Adolescent Health 53 (2): 180-86. https://doi.org/10.1016/i.jadohealth.2013.02.02 1

Frey, Karin S., Miriam K. Hirschstein, and Barbara A. Guzzo. 2000. "Second Step: Preventing Aggression by Promoting Social Competence." Journal of Emotional and Behavioral Disorders 8 (2): 10212.

https://doi.org/10.1177/106342660000800206

Froeschle, J. and Moyer, M. (2004). Just cut it out: Legal and ethical challenges in counseling students who selfmutilate. Professional School Counseling, 231-235.

Grabow, Chip, and Lisa Rose. 2018. "School Shootings in the US Compared with the Rest of the World CNN." CNN, May 21, 2018. https://www.cnn.com/2018/05/21/us/schoolshooting-us-versus-world-trnd/index.html

Josephson Institute of Ethics. 2012. "2012 Report Card on the Ethics of American Youth." Josephson Institute of Ethics National Office. https://b3vj2d40qhgsjw53vra221dqwpengine.netdna-ssl.com/wpcontent/uploads/2014/02/ReportCard-2012DataTables.pdf

Kern, Lee, Sarup R. Mathur, Susan F. Albrecht, Scott Poland, Mike Rozalski, and Russell J. Skiba. 2017. "The Need for School-Based Mental Health Services and Recommendations for Implementation." School Mental Health 9 (3): 205-17. https://doi.org/10.1007/s12310-017-9216-5
Langer, David A., Jeffrey J. Wood, Patricia A. Wood, Ann F. Garland, John Landsverk, and Richard L. Hough. 2015. "Mental Health Service Use in Schools and Non-School-Based Outpatient Settings: Comparing Predictors of Service Use." School Mental Health 7 (3): 161-73. https://doi.org/10.1007/s12310-015-9146-z

Langman, Peter. 2009. "Rampage School Shooters: A Typology." Aggression and Violent Behavior 14 (1): 79-86. https://doi.org/10.1016/i.avb.2008.10.003

Lapan, Richard T., Norman C. Gysbers, Bragg Stanley, and Margaret E. Pierce. 2012. "Missouri Professional School Counselors: Ratios Matter, Especially in High-Poverty Schools." Professional School Counseling 16 (2): 2156759X0001600207. https://doi.org/10.1177/2156759X0001600207

Lee, J.H. 2013. "School Shootings in the U.S. Public Schools: Analysis through the Eyes of an Educator." Review of Higher Education \& Self-Learning 6 (22): 88119.

Low, Sabina, Clayton R. Cook, Keith Smolkowski, and Jodie Buntain-Ricklefs. 2015. "Promoting SocialEmotional Competence: An Evaluation of the Elementary Version of Second Step®." Journal of School Psychology 53 (6): 463-77. https://doi.org/10.1016/j.jsp.2015.09.002

Mann, Angela, Amir Whitaker, Sylvia Torres-Gullien, Michelle Morton, Harold Jordan, Stefanie Coyle, and Wei-Lung Sun. "Cops \& No Counselors: How the Lack of School Mental Health Staff Is Harming Students." (2019).

Merikangas, Kathleen Ries, Jian-Ping He, Marcy Burstein, Sonja A. Swanson, Shelli Avenevoli, Lihong Cui, Corina Benjet, Katholiki Georgiades, and Joel Swendsen. 2010. "Lifetime Prevalence of Mental Disorders in U.S. Adolescents: Results from the National Comorbidity Survey Replication-Adolescent Supplement (NCS-A)." Journal of the American Academy of Child and Adolescent $\begin{array}{llll}\text { Psychiatry } & 49 & \text { (10): } & 980-89 .\end{array}$ https://doi.org/10.1016/i.jaac.2010.05.017

O’Toole, Mary Ellen. 1999. The School Shooter: A Threat Assessment Perspective. For full text: https://eric.ed.gov/?id=ED446352

Paolini, Allison. 2015. "School Shootings and Student Mental Health: Role of the School Counselor in Mitigating Violence." Vistas Online 90: 1-17.

Reback, Randall. 2010. "Schools' Mental Health Services and Young Children's Emotions, Behavior, and Learning." Journal of Policy Analysis and Management $29 \quad$ (4): $\quad 698-725$. https://doi.org/10.1002/pam.20528 
Riedman, David, and Desmond O'Neill. 2018. “K-12 School Shooting Database: Research Methodology." Naval Postgraduate School Center for Homeland Defense and Security Homeland Security Advanced Thinking Program. https://www.chds.us/ssdb/resources/uploads/2 018/10/Intro-and-Methodology-K-12-SSDB.pdf

Riedman, David, and Desmond O'Neill. 2020. "CHDS - K-12 School Shooting Database." Center for Homeland Defense and Security. Accessed March 31, 2020. https://www.chds.us/ssdb/dataset/

Second Step. 2020 "Social-Emotional Learning Curriculum." Accessed April 12, 2020. https://www.secondstep.org/second-step-socialemotional-learning

Substance Abuse and Mental Health Services Administration (SAMHSA), Center for Behavioral Health Statistics and Quality (CBHSQ), and U.S. Department of Health and Human Services (HHS). 2010. "Results from the 2010 NSDUH: Mental Health Findings." 2010. https://www.samhsa.gov/data/sites/default/file s/2k10MH Findings/2k10MH Findings/2k10MH Results.htm\#3.2
Vossekuil, Bryan, Robert A Fein, Marisa Reddy, Randy Borum, and William Modzeleski. 2002. "The Final Report and Findings of the Safe School Initiative: Implications for the Prevention of School Attacks in the United States." United States Secret Service and United States Department of Education. https://permanent.access.gpo.gov/lps22579/ssi final report.pdf

Wenz-Gross, Melodie, Yeonsoo Yoo, Carole C. Upshur, and Anthony J. Gambino. 2018. "Pathways to Kindergarten Readiness: The Roles of Second Step Early Learning Curriculum and Social Emotional, Executive Functioning, Preschool Academic and Task Behavior Skills." Frontiers in Psychology 9 (October). https://doi.org/10.3389/fpsyg.2018.01886

Wike, Traci L., and Mark W. Fraser. 2009. "School Shootings: Making Sense of the Senseless." Aggression and Violent Behavior 14 (3): 162-69. https://doi.org/10.1016/i.avb.2009.01.005

Agnes Varghese is a graduate student researcher at the University of California, Riverside (UCR), pursuing a $\mathrm{PhD}$ in Developmental Psychology. She holds a BS in Psychology and a BA in Broadcast Journalism from the University of Maryland, College Park. Agnes is the Chair of External Affairs for the UCR Center for Science to Policy's student-led cabinet.

Danielle Delany is a graduate student researcher at the University of California, Riverside (UCR), pursuing a $\mathrm{PhD}$ in Developmental Psychology. She holds a BA and MA in Psychology from California State University, Fullerton. Danielle is the Chair of the Education and Events Committee for the UCR Center for Science to Policy's student-led cabinet.

Morgan Dundon is a graduate student researcher and National Science Foundation Graduate Research Fellow at the University of California, Riverside (UCR), pursuing a PhD in Materials Science and Engineering. She holds a BS in Forensic Chemistry and Chemistry from Towson University. Morgan is the Chair of Government Relations for the UCR Center for Science to Policy's student-led cabinet.

\section{Acknowledgements}

The authors would like to acknowledge the contributions of the Center for Science to Policy at the University of California, Riverside in preparing this manuscript. 